\title{
Under-Paid Shop Stewards: A Case of Strategic Discrimination?
}

An Econometric Analysis Using 2010 REPONSE Data

Jérôme Bourdieu and Thomas Breda

Translator. Andrew Clark

\section{(2) OpenEdition}

\section{Journals}

Electronic version

URL: http://journals.openedition.org/travailemploi/7613

DOI: 10.4000/travailemploi.7613

ISSN: 1775-416X

Publisher

DARES - Ministère du Travail

\section{Printed version}

Date of publication: 30 December 2017

Number of pages: 5-30

ISSN: 0224-4365

\section{Electronic reference}

Jérôme Bourdieu and Thomas Breda, "Under-Paid Shop Stewards: A Case of Strategic

Discrimination?", Travail et Emploi [Online], Hors-série | 2017, Online since 11 July 2019, connection on 13 April 2021. URL: http://journals.openedition.org/travailemploi/7613 ; DOl: https://doi.org/10.4000/ travailemploi.7613 


\title{
Under-Paid Shop Stewards: A Case of Strategic Discrimination?
}

\section{An Econometric Analysis Using 2010 REPONSE Data*}

\author{
Jérôme Bourdieu**, Thomas Breda ${ }^{* * *}$
}

\begin{abstract}
Instances of discrimination against union members continue to accumulate in France, as can be seen by the multiplication of legal proceedings and judgements against a number of large firms. This qualitative impression was underpinned by the statistical results from the 2004 French REPONSE (Relations professionnelles et négociations d'entreprise) survey (the equivalent of the British Workplace Employment Relations Survey), revealing that, at the same age and education, union representatives are paid around $10 \%$ less than their colleagues. We here confirm this result in the 2010 wave of the same survey. Union membership does not suffice to explain these lower wages: it is rather shop stewards, who are the most active in the defence of workers' interests, who are the most heavily penalised. It is in practice difficult to establish that these workers receive lower wages for reasons other than their union responsibilities. The wage gap for union members who are not representatives is much smaller, at around $4 \%$, while it is in firms that experience conflictual labour relations that shop stewards are paid the least.
\end{abstract}

$\mathrm{I}^{\mathrm{n}}$

n a macroeconomic environment of persistent unemployment and slow growth, the perspective of job loss is frightening, and the defence of workers' interests can become increasingly difficult. In this context, there has been growing qualitative evidence of discrimination against union members. ${ }^{1}$ Since 2000, a number of large

\footnotetext{
* Translation: Andrew Clark.

Article published in French in Travail et Emploi, no 145, janvier-mars 2016.

Support from the Direction de l'animation de la recherche, des études et des statistiques (Department for the Coordination of Research, Studies and Statistics - DARES) is gratefully acknowledged.

** Paris School of Economics (PSE), Institut national de recherche agronomique (INRA) and École des hautes études en sciences sociales (EHESS); jerome.bourdieu@ens.fr.

*** PSE and Centre national de la recherche scientifique (CNRS); thomas.breda@ens.fr.

1. See for example the numerous individual testimonies in the annual report of the Observatoire des répressions et discriminations syndicales (Union Repression and Discrimination Observatory).
} 
French firms have paid out compensation to dozens of individuals following lawsuits alleging union discrimination (SEMAINE SOCIALE LAMY, 2004).

These particular cases could be exceptional or atypical: the experiences and testimony of these individuals may not correspond to the reality of most workers. However, the results from the analysis of the 2004 Relations professionnelles et négociations d'entreprise (REPONSE) survey carried out by the Direction de l'animation de la recherche, des études et des statistiques (DARES) suggest that this is actually a widespread phenomenon, with a pay gap of around $10 \%$ between shop stewards and their non-unionised colleagues, once observable characteristics (like sex, age and education) have been controlled for (BREDA, 2014). The analogous wage gap for workers who are union members (but not shop stewards) is smaller and not statistically significant.

These results suggest that workers are penalised according to the extent of their engagement in the defence of their collective interests. We here investigate this hypothesis using the latest wave of the REPONSE survey, which provides greater detail on the degree of worker engagement.

We have four groups of employees, split up by union status and the degree of worker representation. The first group (the control group here) are neither unionised nor worker representatives. We then have worker representatives who are not unionised, and union members who are not representatives. The fourth group includes workers who are both unionised and representatives. Of these, only some (around a third) participate in official bargaining and have the mandate to sign off on the resulting agreements: these are the Délégués syndicaux and we will call them shop stewards.

The new question that appears in the 2010 survey allows us to estimate the 2010 wage gap between worker representatives who are union members, worker representatives who are not union members and their colleagues. Our aim is thus to see whether the wage gap of shop stewards results from their union membership or rather from their activism. This produces a finer description of the way in which workers' interests are defended in firms, taking into account both the type of negotiation forum (e.g., obligatory annual negotiations versus consultation) and union membership.

Using an indirect method of identifying shop stewards, we reveal their particular outcomes: as we will see, they suffer from the greatest wage penalties, with other union members, whether they are worker representatives or not, having smaller penalties and non-unionised worker representatives no wage penalty at all. The analysis of the promotions, both past and future, and socio-professional categories of these different groups of workers shows that the observed wage gaps result from different promotion rates. In addition, these wage gaps are not found in all firms. For example, when a firm specifically negotiates over union organisation and employee expression rights, or when the obligatory annual negotiations do not take place (even though they should have done), neither unionised worker representatives nor shop stewards suffer any wage penalty. Our first section will present these results. 
After having set out the position of worker representatives in the bargaining process, we propose a theoretical interpretation of the wage penalties uncovered by our statistical analysis: these are argued to reflect a "strategic" discrimination that aims to protect the interests of employers for whom bargaining, in particular over wages, can be costly. Other potential interpretations (taste-based discrimination, adverse selection, statistical discrimination, and self-censorship by shop stewards) will also be discussed, particularly with respect to the particularity of union engagement. As the available data do not allow us to reach a conclusion about the causal mechanisms behind our results, the discussion aims to clarify the different concepts of discrimination and adverse selection, and their limits when applied to the case of worker representatives. These latter dedicate part of their work time to their representation activity: they therefore do not carry out exactly the same tasks as their non-representative colleagues, so that it is not formally possible to show that they do not receive equal pay for equal work.

\section{Wage and Promotion Gaps between Worker Representatives, Union Members and Other Workers}

The data from the 2010 REPONSE survey (Box 1) allow us to identify the wages of worker representatives. These thus provide a direct measure of the wage gap that the latter may suffer from their official status of representing workers' interests. This measure may be seen as a validation of the results obtained for shop stewards in the 2004 REPONSE data (BREDA, 2014) of a wage gap using an indirect identification method that will be described below: shop stewards were paid on average $10 \%$ less than the colleagues that they represented, given their observable characteristics (education, age, tenure, etc.). This wage gap grew with tenure, the discrimination that the representatives reported, and membership of more campaigning unions such as the Confédération générale du travail (General Confederation of Labour - CGT).

\section{Box 1}

\section{The REPONSE Survey Matched to DADS ${ }^{1}$}

The empirical analysis is carried out using the three parts of the REPONSE surveys from 2004 and 2010. ${ }^{2}$

The REPONSE survey is managed by the DARES, and is one of the main sources of data on industrial relations in France. It is carried out every six years on a sample,

1. The DADS survey is the Déclarations annuelles de données sociales (Annual Declaration of Social Data).

2. The surveys actually cover the years 2004-2005 and 2010-2011, but are matched to wage data from DADS for 2003 and 2009 respectively. For simplicity, we will label these estimations as covering 2004 and 2010, but these slight anachronisms should be kept in mind. 
in 2010, of 4,000 establishments with 10 employees or more in the non-farm business sector. $^{3}$ A management representative completes a long face-to-face interview in each establishment, and replies to a large number of questions covering notably the organisation of work, the technologies used, and industrial relations. The replies of the management representative constitute the employer part of the survey. When there is one or more worker representative in the establishment, the employer is asked to provide the name of one of the principal establishment worker representatives. These representatives are then interviewed. In 2010 we have a sample of 2,433 interviews in the "worker representative" part of the survey. Last, the "employee" part of the survey comes from a random sample of 10 employees per establishment who receive a questionnaire by mail (in each establishment, all employees with over one year of tenure have the same probability of being interviewed). Given the response rate of around $30 \%$, which is typical for mail surveys, the final sample includes information on just under three employees per establishment on average. When we match the employer and employee parts of the survey, we have in 2010 a sample of 11,334 employees in 4,023 establishments.

As the employee parts of the REPONSE surveys in 2004 and 2010 had already been matched to the DADS dataset by the DARES, we have information on the net hourly wage of each employee in the final sample as of December 31st 2009 for the 2010 survey, and December 31st 2003 for the 2004 survey. The DADS data are also used as an alternative source for some other variables, such as establishment size.

3. Previous waves covered establishments with 50 employees or more in 1992, and establishments with 20 employees or more in 1998 and 2004, each time in the non-farm business sector.

\section{The Wages of Unionised and Non-Unionised Worker Representatives, and of Unionised Non-Representatives}

Table 1 presents in detail our estimations of the wage gap between unionised and non-unionised worker representatives, on the one hand, and workers who are neither unionised nor representatives (who are the reference category here ${ }^{2}$ ). The average wage gap (without any control variables) between these groups is only small (under 1.5\%) and insignificant (column 1). When we include control variables for education, sex, age and age-squared, and some basic establishment characteristics (industry, size, age and presence of a shop steward ${ }^{3}$ ) into the wage equation, we find a wage penalty of $3.5 \%$ for unionised representatives relative to workers who are neither unionised nor representatives. Non-unionised worker representatives do

2. These estimations cover full-time permanent workers, excluding apprentices, interns and second jobs, with annual declared hours between 900 and 2,200, working in establishments with 10 employees or more in the non-farm business sector. The estimations are weighted to ensure the representativeness of the workers in the sample. These restrictions and their effect on the results are discussed in the Appendix.

3. The linear regression method used here allows us to estimate the linear relationship between the wage and a number of other variables that may be of interest (here union status and being a worker representative) or act as controls. The wage gaps that are estimated for union members and/or worker representatives are thus corrected for observable differences between workers in terms of the control variables introduced in the regression. 
TABLE 1 - Wage Gaps between Worker Representatives, Union Members and their Colleagues in 2009

\begin{tabular}{|c|c|c|c|c|c|c|c|}
\hline \multicolumn{8}{|c|}{ Dependent Variable: $\log$ of hourly wages (DADS 2009} \\
\hline & (1) & (2) & (3) & (4) & (5) & (6) & (7) \\
\hline $\begin{array}{l}\text { Unionised, not } \\
\text { representatives }\end{array}$ & $\begin{array}{c}0.014 \\
(0.014)\end{array}$ & $\begin{array}{c}-0.038^{* * * *} \\
(0.013)\end{array}$ & $\begin{array}{c}-0.044 * * * \\
(0.013)\end{array}$ & $\begin{array}{l}-0.002 \\
(0.011)\end{array}$ & $\begin{array}{c}-0.033 * * * \\
(0.012)\end{array}$ & $\begin{array}{c}-0.037 * * * \\
(0.012)\end{array}$ & $\begin{array}{l}-0.008 \\
(0.010)\end{array}$ \\
\hline $\begin{array}{l}\text { Unionised } \\
\text { representatives }\end{array}$ & $\begin{array}{l}-0.003 \\
(0.018)\end{array}$ & $\begin{array}{c}-0.035^{* *} \\
(0.016)\end{array}$ & $\begin{array}{c}-0.046^{* * * *} \\
(0.016)\end{array}$ & $\begin{array}{l}-0.001 \\
(0.013)\end{array}$ & $\begin{array}{c}-0.034 * * \\
(0.014)\end{array}$ & $\begin{array}{c}-0.049 * * * \\
(0.014)\end{array}$ & $\begin{array}{l}-0.011 \\
(0.011)\end{array}$ \\
\hline $\begin{array}{l}\text { Non-unionised } \\
\text { representatives }\end{array}$ & $\begin{array}{l}-0.012 \\
(0.021)\end{array}$ & $\begin{array}{l}-0.005 \\
(0.019)\end{array}$ & $\begin{array}{l}-0.017 \\
(0.019)\end{array}$ & $\begin{array}{l}-0.001 \\
(0.016)\end{array}$ & $\begin{array}{c}0.005 \\
(0.016)\end{array}$ & $\begin{array}{c}-0.008 \\
(0.016)\end{array}$ & $\begin{array}{l}-0.001 \\
(0.013)\end{array}$ \\
\hline Observations & 12,318 & 7,695 & 7,606 & 7,606 & 12,189 & 12,046 & 12,046 \\
\hline$R^{2}$ & 0.000 & 0.490 & 0.503 & 0.667 & 0.794 & 0.801 & 0.871 \\
\hline Worker controls & No & Mincer & $\begin{array}{l}\text { Mincer } \\
+ \text { tenure }\end{array}$ & Detailed & Mincer & $\begin{array}{l}\text { Mincer } \\
+ \text { tenure }\end{array}$ & Detailed \\
\hline $\begin{array}{l}\text { Establishment } \\
\text { controls }\end{array}$ & No & Yes & Yes & Yes & $\begin{array}{l}\text { Fixed } \\
\text { effects }\end{array}$ & $\begin{array}{l}\text { Fixed } \\
\text { effects }\end{array}$ & $\begin{array}{l}\text { Fixed } \\
\text { effects }\end{array}$ \\
\hline Weighted & Yes & Yes & Yes & Yes & Yes & Yes & Yes \\
\hline
\end{tabular}

Note: All regressions are weighted at the employee level using the weights supplied by the DARES with the survey. The individual-level controls called "Mincer" are education ( 9 categories), age (in years), age-squared and sex. The individual controls called "Detailed" include in addition tenure and tenure-squared, socio-professional group (4 categories) and the number of hours worked. The "Standard" establishment controls are size (5 categories), industry (16 categories), region (10 categories), age ( 5 categories) and a dummy for the presence of a union representative. Standard errors are in parentheses. $* * * \mathrm{p}<0.01, * * \mathrm{p}<0.05, * \mathrm{p}<0.1$.

Interpretation: Without any control variables (column 1), the log hourly wage of a non-representative union member is 0.014 higher on average than that of a worker who is neither unionised nor a representative (the control group).

Field: Full-time permanent workers, excluding apprentices, interns and second jobs, with annual declared hours between 900 and 2,200 , working in establishments with 10 employees or more in the non-farm business sector.

Source: The employer and employee parts of the 2010 REPONSE survey, matched to DADS data.

not however suffer from any wage penalty, while the wage gap of unionised nonrepresentatives is also about $3.5 \%$ relative to workers who are neither unionised nor representatives (column 2).

The most important explanatory variables behind the change in the wage gaps between columns 1 and 2 are age and establishment size: worker representatives are older and are more likely to be found in larger establishments than workers in the control group (Table 2), and both age and establishment size are associated with higher hourly wages. Adding worker tenure (as a quadratic) increases the wage penalty for unionised worker representatives somewhat to $4.5 \%$ (column 3 of Table 1): union members and worker representatives both have longer establishment tenure, and so higher wages. 
TABLE 2 - Percentage of Union Members and Worker Representatives by Establishment Characteristics and Worker Socio-Demographic Characteristics

As a \% of workers

\begin{tabular}{|c|c|c|c|c|c|c|}
\hline & $\begin{array}{c}\text { Worker } \\
\text { representative }\end{array}$ & $\begin{array}{l}\text { Non-unionised } \\
\text { worker } \\
\text { representative }\end{array}$ & $\begin{array}{c}\text { Unionised } \\
\text { worker } \\
\text { representative }\end{array}$ & $\begin{array}{l}\text { Unionised } \\
\text { member }\end{array}$ & $\begin{array}{c}\text { Ex-union } \\
\text { member }\end{array}$ & $\begin{array}{c}\text { Proportion of } \\
\text { representatives } \\
\text { among union } \\
\text { members }\end{array}$ \\
\hline All & 6.4 & 2.8 & 3.6 & 11.0 & 8.9 & 32.9 \\
\hline \multicolumn{7}{|l|}{ Sex } \\
\hline Men & 6.9 & 2.9 & 4.0 & 11.8 & 10.1 & 34.1 \\
\hline Women & 5.7 & 2.7 & 3.0 & 9.8 & 7.2 & 31.0 \\
\hline \multicolumn{7}{|c|}{ Socio-professional category } \\
\hline $\begin{array}{l}\text { Blue-collar } \\
\text { workers }\end{array}$ & 6.7 & 2.6 & 4.1 & 12.8 & 10.0 & 32.4 \\
\hline $\begin{array}{l}\text { White-collar } \\
\text { employees }\end{array}$ & 6.3 & 2.9 & 3.3 & 9.6 & 7.6 & 34.4 \\
\hline $\begin{array}{l}\text { Intermediate } \\
\text { professions }\end{array}$ & 7.3 & 3.1 & 4.3 & 12.6 & 10.3 & 33.9 \\
\hline Managers & 4.9 & 2.7 & 2.2 & 7.4 & 6.9 & 30.2 \\
\hline \multicolumn{7}{|l|}{ Education } \\
\hline No qualifications & 5.4 & 2.2 & 3.1 & 13.1 & 10.6 & 23.7 \\
\hline $\begin{array}{l}\text { Below the } \\
\text { baccalauréat }\end{array}$ & 6.9 & 2.6 & 4.3 & 12.3 & 12.0 & 35.3 \\
\hline Baccalauréat & 6.4 & 3.0 & 3.4 & 12.1 & 8.2 & 28.3 \\
\hline $\begin{array}{l}\text { Over the } \\
\text { baccalauréat }\end{array}$ & 6.3 & 3.1 & 3.2 & 8.7 & 5.7 & 36.8 \\
\hline \multicolumn{7}{|l|}{ Working Hours } \\
\hline Full-time & 6.8 & 2.9 & 4.0 & 11.3 & 9.0 & 34.9 \\
\hline Part-time & 4.0 & 2.2 & 1.8 & 9.2 & 8.2 & 19.8 \\
\hline \multicolumn{7}{|l|}{ Sector } \\
\hline Industry & 6.8 & 3.0 & 3.8 & 10.4 & 8.2 & 36.8 \\
\hline Construction & 6.7 & 2.4 & 4.3 & 15.6 & 14.8 & 27.7 \\
\hline Retail & 7.4 & 3.6 & 3.9 & 8.8 & 5.8 & 44.3 \\
\hline Services & 6.5 & 2.9 & 3.5 & 10.8 & 8.8 & 32.9 \\
\hline \multicolumn{7}{|l|}{ Establishment size } \\
\hline 10-19 workers & 5.0 & 3.3 & 1.7 & 5.0 & 7.3 & 34.0 \\
\hline 20-49 workers & 6.3 & 3.7 & 2.5 & 7.8 & 7.9 & 32.6 \\
\hline 50-99 workers & 9.0 & 4.9 & 4.2 & 9.9 & 9.8 & 42.6 \\
\hline 100-199 workers & 8.1 & 3.7 & 4.5 & 13.3 & 8.6 & 33.6 \\
\hline 200-999 workers & 6.5 & 1.0 & 5.5 & 15.2 & 9.0 & 36.2 \\
\hline$>1000$ workers & 3.6 & 0.2 & 3.4 & 14.7 & 12.2 & 23.0 \\
\hline
\end{tabular}

Note: All statistics are weighted at the employee level using the weights supplied by the DARES with the REPONSE data.

Field: Workers in establishments with 10 employees or more in the non-farm business sector.

Source: The employer and employee parts of the 2010 REPONSE survey, matched to DADS data. 
The addition of variables reflecting hours of work and worker socio-professional category (split into four groups: blue-collar workers, white-collar employees, intermediate professions, and managers) reduces the hourly wage gap between unionised workers, worker representatives and their colleagues to zero (column 4): comparing worker representatives to other workers of the same socio-professional category, the wage penalty disappears. This does not mean (and we will return to this point) that there is no wage penalty, but rather that this wage penalty cannot be considered independently of other employer-choice variables, such as promotions for example, which can also be used to discriminate against employees.

The last set of specifications aims to pick up any differences between establishments in terms of wage policy by introducing fixed effects. Columns 5 to 7 of Table 1 reproduce columns 2 to 4, but with establishment fixed effects rather than establishment-level controls. Conceptually, this means that we compare union representatives and/or union members, and their colleagues who are neither one nor the other, establishment by establishment, so that the measured wage gaps between the different categories of workers do not reflect wage differences between, for example, establishments where there are worker representatives and establishments where there are none. These fixed-effect results are similar to those without fixed effects.

Overall, the wage gap between unionised workers (whether they are worker representatives or not), and their non-unionised colleagues (again, whether they are worker representatives or not) is around $3.5 \%$ in 2010, considering workers of the same sex, experience, education and in the same establishment. These results suggest that it is union membership rather than being a worker representative that produces wage penalties.

\section{As in 2004, Shop Stewards Were Less Well-Paid in 2010}

The wage penalty suffered by unionised worker representatives in 2010 is notably smaller than that for shop stewards in 2004 (as estimated in BREDA, 2014). There are a number of potential explanations of this change. First, there are differences in the way in which the wage penalty is estimated: this was indirect and less precise in 2004; the survey in 2010 now includes firms with 10 to 20 employees; and the key right-hand side variable is not the same, as we have switched from shop stewards to unionised worker representatives. Second, any change in the wage gap between 2004 and 2010 could reflect real changes in the labour market that took place over that period. The tests that we have carried out indicate that it is the change in the right-hand side variable that is mostly behind the change in the results (see BOURDIEU, BREDA, 2015, for a detailed analysis).

While the distinction between shop stewards and unionised worker representatives may seem only minor to someone who is not a specialist in industrial relations, this is in fact far from the case regarding the duties that they carry out. There are far fewer shop stewards than unionised worker representatives. Estimations carried 
out using REPONSE data suggest that there are around 100,000 shop stewards and 300,000 unionised worker representatives in France in establishments with 10 employees or more in the non-farm business sector (Table 3). As such, only one unionised worker representative in three is a shop steward. The other unionised worker representatives are, for example, worker delegates, other union branch managers, or union members of the works council or the health and safety committee. The main difference between shop stewards and the other unionised worker representatives concerns the jobs they do: shop stewards are responsible for the negotiation of the collective agreements with the firm, notably during the obligatory annual bargaining round covering wages and work conditions, while the other unionised worker representatives essentially play a consultative role and aid communication between the firm and its workers. Their engagement in bargaining that, in theory, should reduce the share of value-added going to the firm puts shop stewards in a notably different position. And it is in this group that the wage penalty is the highest.

TABLE 3 - The Distribution of Employees by Union and Worker-Representative Status

\begin{tabular}{|c|c|c|c|c|c|c|}
\hline \multirow[b]{3}{*}{ Non-unionised, not representatives } & & & & & & Unit and $\mathrm{C}$ \\
\hline & \multicolumn{2}{|c|}{ Whole sample } & \multicolumn{2}{|c|}{ Analysis sample } & \multicolumn{2}{|c|}{$\begin{array}{c}\text { Population } \\
\text { represented by the } \\
\text { survey (in thousands of } \\
\text { employees in the left- } \\
\text { hand column) }\end{array}$} \\
\hline & 15,702 & 86.1 & 10,832 & 85.3 & 7,921 & 86.2 \\
\hline Non-unionised representatives & 543 & 3.0 & 405 & 3.2 & 256 & 2.8 \\
\hline Unionised, not representatives & 1,316 & 7.2 & 908 & 7.2 & 678 & 7.4 \\
\hline Unionised representatives & 672 & 3.7 & 548 & 4.3 & 332 & 3.6 \\
\hline Of which Shop Stewards & $\approx 124$ & $\approx 0.7$ & $\approx 93$ & $\approx 0.7$ & $\approx 93$ & $\approx 1.0$ \\
\hline Total & 18,233 & 100.0 & 12,693 & 100.0 & 9,188 & 100.0 \\
\hline
\end{tabular}

Note: All statistics are weighted at the employee level using the weights supplied by the DARES with the REPONSE data. For more details on the estimation of the number of shop stewards, see BOURDIEU, BREDA, 2015.

Field: Full-time permanent workers, excluding apprentices, interns and second jobs, with annual declared hours between 900 and 2,200, working in establishments with 10 employees or more in the non-farm business sector.

Source: The employer and employee parts of the 2010 REPONSE survey, matched to DADS data.

In order to estimate the particular wage penalty of shop stewards, we need to use, in the 2010 data, an indirect identification method analogous to that used for the 2004 data (Box 2). Shop stewards are not directly identifiable in the "employee" part of the 2010 REPONSE survey.

Using the 2004 method, which identifies the probability of being a shop steward via the percentage of the latter among union members, we find in the 2010 data a wage penalty of around $6 \%$ for shop stewards, controlling for education, sex, worker experience, and establishment characteristics. This gap falls a little to $5 \%$ when we 
Box 2

Three Indirect Identification Strategies for Shop Stewards in 2010

We can estimate the probability that a union member be a shop steward using the answers given by management representatives about the number of shop stewards and the percentage of union members in the establishment. Multiplying this declared percentage of union members by establishment size (which we know from the DADS database), we obtain the number of establishment union members. Dividing the number of shop stewards by the number of union members yields the establishment proportion of shop stewards amongst the unionised. As the workers in the survey are drawn at random, this proportion corresponds to the probability that a unionised worker in an establishment be a shop steward. If the worker is not unionised, the probability of being a shop steward is automatically zero (shop stewards have to be union members). This probability, which varies from establishment to establishment, is thus sufficient to estimate the average wage gap between shop stewards and their colleagues (under the assumption that this gap does not vary with this calculated probability: see BREDA, 2014).

This "probabilistic" method was previously applied to the 2004 data. In the 2010 survey we can instead use information from a new question on the number of worker representatives, which produces a more accurate estimation of the shop-steward wage penalty. In 2010 the employer provides information on the number of worker representatives and unionised worker representatives: we use this information to identify shop stewards, not among the set of union members but rather among the more restricted sets of worker representatives or even unionised worker representatives. The wage penalty for shop stewards is obtained using information about whether the worker is a worker representative (unionised worker representative) with the probability that a worker representative (unionised worker representative) be a shop steward. This method requires assumptions over the number of mandates held concurrently by unionised worker representatives (see BOURDIEU, BREDA, 2015, for details).

add establishment fixed effects. These wage gaps are not statistically significant due to the inherent imprecision of the method used, but do suggest a greater wage penalty for shop stewards.

The three probabilistic identification methods used in 2010 (Box 2) are in line with the above result. Controlling for the differences in worker experience and education and the differences in establishment size and industry, the wage penalty for shop stewards is estimated to be around 5\% when compared to the set of worker representatives, and $12 \%$ compared to the smaller group of unionised worker representatives. These wage gaps are larger, at around 10 to $15 \%$, in our preferred specification that includes establishment fixed effects. ${ }^{4}$

4. The full set of results can be found in Bourdieu, BredA (2014), Tables 5A, 5B, 5C, and A3, A4, A5. 
Each of these three probabilistic identification methods for shop stewards produces results that are not very precise, in statistical terms, as a result of the indirect identification. When probabilistic identification is based on worker representatives, the results are nonetheless improved relative to 2004, due to the greater proportion of shop stewards among worker representatives than among union members. In addition, the three measures of the wage gap that we propose are consistent in the sense that wage penalties are higher for shop stewards. Given our different estimates that all point in the same general direction, we conclude as to a wage gap of around $10 \%$ for shop stewards, although this figure is only inaccurately estimated.

In conclusion, our analysis of the union wage gap reveals two phenomena: union members are paid less than their non-union colleagues, and this gap is larger for those who have official worker representation responsibilities. And this latter does not represent worker representation as such, as we find no evidence of it for nonunion worker representatives.

\section{Wage Gaps Are Explained by Differences in Promotion}

Wage gaps, whether for all union members, unionised worker representatives or shop stewards, disappear when we control for socio-professional category (Table 1, columns 4 and 7). As such, union wage penalties, given age, sex and education, are explained by the various types of union members having different jobs than their colleagues. This suggests that wage gaps may reflect differences in promotion, as current socio-professional category depends on past promotions.

This is confirmed in Table 4, which shows that, controlling for age, sex and education, union members (whether they be worker representatives or not) have at least a 5\% lower chance of having been promoted in the past three years than workers who are neither unionised nor representatives (columns 1 and 2). The results in Table 4 are in line with those that we found earlier for wages: it is not being a worker representative as such that matters, but rather union membership. In particular, nonunionised worker representatives do not have lower promotion rates.

The phenomenon is actually more complex than Table 4 suggests: first, shop stewards are less likely to be promoted than union members (the statistical results are not shown here) but, at the same time, non-unionised worker representatives are clearly more likely to be promoted than non-union non-representative workers (the control group). The sample average promotion rate over the past three years is $25 \%$ : the promotion rate of non-unionised representatives is thus estimated to be double that of unionised representatives (at 17\% and 33\% respectively, in column 2's fixed effect specification ${ }^{5}$.

\footnotetext{
5. These large gaps in terms of past promotion are also found in future promotion prospects (columns 3 and 4). These results are estimated only controlling for worker characteristics that are not at the employer's discretion: age, sex and education.
} 
TABLE 4 - Worker Representatives and Union Members: Promotion, Pay Rises and Job Loss

\begin{tabular}{|c|c|c|c|c|c|c|}
\hline & \multicolumn{2}{|c|}{$\begin{array}{c}\text { Promoted in the last } \\
3 \text { years }\end{array}$} & \multicolumn{2}{|c|}{$\begin{array}{l}\text { Probability of promotion } \\
\text { or wage rise over the next } \\
12 \text { months }\end{array}$} & \multicolumn{2}{|c|}{$\begin{array}{l}\text { Probability of job loss } \\
\text { over the next } 12 \text { months }\end{array}$} \\
\hline & (1) & (2) & (3) & (4) & (5) & (6) \\
\hline $\begin{array}{l}\text { Unionised, not } \\
\text { representatives }\end{array}$ & $\begin{array}{l}-0.049 * * \\
(0.020)\end{array}$ & $\begin{array}{c}-0.080 * * * \\
(0.021)\end{array}$ & $\begin{array}{l}-0.134 * * * \\
(0.050)\end{array}$ & $\begin{array}{c}-0.238 * * * \\
(0.052)\end{array}$ & $\begin{array}{l}0.257 * * * \\
(0.052)\end{array}$ & $\begin{array}{l}0.191 * * * \\
(0.050)\end{array}$ \\
\hline $\begin{array}{l}\text { Unionised } \\
\text { representatives }\end{array}$ & $\begin{array}{c}-0.058 * * \\
(0.024)\end{array}$ & $\begin{array}{c}-0.074 * * * \\
(0.025)\end{array}$ & $\begin{array}{c}-0.214 * * * \\
(0.059)\end{array}$ & $\begin{array}{c}-0.236 * * * \\
(0.060)\end{array}$ & $\begin{array}{l}0.269 * * * \\
(0.061)\end{array}$ & $\begin{array}{l}0.170 * * * \\
(0.056)\end{array}$ \\
\hline $\begin{array}{l}\text { Non-unionised } \\
\text { representatives }\end{array}$ & $\begin{array}{c}0.084 * * * \\
(0.030)\end{array}$ & $\begin{array}{c}0.080 * * * \\
(0.029)\end{array}$ & $\begin{array}{c}0.228 * * * \\
(0.072)\end{array}$ & $\begin{array}{c}0.222 * * * \\
(0.072)\end{array}$ & $\begin{array}{l}-0.107 \\
(0.071)\end{array}$ & $\begin{array}{l}-0.061 \\
(0.066)\end{array}$ \\
\hline Observations & 7,369 & 11,705 & 6,175 & 9,800 & 5,927 & 9,397 \\
\hline$R^{2}$ & 0.062 & 0.517 & 0.082 & 0.591 & 0.049 & 0.651 \\
\hline Worker controls & Mincer & Mincer & Mincer & Mincer & Mincer & Mincer \\
\hline $\begin{array}{l}\text { Establishment } \\
\text { controls }\end{array}$ & Yes & Fixed effects & Yes & Fixed effects & Yes & Fixed effects \\
\hline Weighted & Yes & Yes & Yes & $Y e s$ & Yes & $Y e s$ \\
\hline
\end{tabular}

Note: The control variables are defined in Table 4. These results come from linear probability models (OLS) with the dependent variables all being standardised to have a standard deviation of 1 .

Interpretation: Unionised worker representatives have a 5.8\% lower chance of having been promoted in the last three years than non-union non-worker representative employees (column 1).

Field: Full-time permanent workers, excluding apprentices, interns and second jobs, with annual declared hours between 900 and 2,200 , working in establishments with 10 employees or more in the non-farm business sector.

Source: The employer and employee parts of the 2010 REPONSE survey.

This sharp contrast between unionised and non-unionised representatives is also found for the declared future promotion probability over the coming year (columns 3 and 4 of Table 4) and the risk of job loss (columns 5 and 6). In particular, we note that the protection against job loss enjoyed by unionised representatives does not prevent them from saying that they are more likely to lose their job than the control group.

\section{Wage Gaps Are Not Systematic}

The REPONSE survey includes information on whether negotiations over union organisation and employee expression rights took place at the establishment or firm level, and if these negotiations led to an agreement. While, in theory, the negotiations identified in the REPONSE survey may not have any bearing on the career of unionised representatives, in practice, according to practitioners in social legislation, union-rights agreements often cover the careers of worker representatives. This is confirmed in the report by CHAPPE et al. (2015). We thus assume that the negotiations identified by this REPONSE question also cover the careers of union representatives.

Between 2008 and 2010, about 30\% of establishments (and 45\% of those with shop stewards) negotiated over union organisation and employee expression rights 
TABLE 5 - The Prevalence of Bargaining Over Union Organisation 2008-2010 and 2002-2004

As a \% of establishments

Conflict $\begin{gathered}\text { Use of the branch } \\ \text { bargaining } \\ \text { agreement }\end{gathered} \quad$ Bargaining

Agreement,

\author{
when
}

bargaining took place

\title{
Between 2008 and 2010
}

All establishments

1.9

71.6

30.2

46.8

Establishments with over 300 employees

61.9

Establishments with a worker representative interviewed

46.5

Establishments with a worker representative and over 300 employees

Establishments with a shop steward

Establishments with a shop steward and over 300 employees

44.8

57.3

59.5

Between 2002 and 2004

All establishments

69.5

32.7

40.1

Establishments with

over 300 employees

Establishments with a worker representative interviewed

69.5

53.2

49.3

Establishments with a worker representative and over 300 employees

Establishments with a shop steward

Establishments with a shop steward and over 300 employees

$51.2 \quad 47.0$

40.8

42.5

50.7

Note: These figures come from the questions asked of management representatives, and refer to the existence of conflicts and negotiations or agreements over the three years preceding the survey (the 2008-2010 period in REPONSE 2010, and the 2002-2004 period for REPONSE 2004).

Interpretation: The proportion of sample establishments that bargained over union organisation and employee expression rights between 2008 and 2010 is $30.2 \%$. This proportion is $58.5 \%$ in establishments belonging to firms with over 300 employees, $34.4 \%$ in those where a worker representative was interviewed, and $44.8 \%$ in those with a shop steward.

Field: Establishments with 10 employees or more in the non-farm business sector.

Source: The employer parts of the 2004 and 2010 REPONSE surveys. 
TABLE 6 - Wage Gaps between Worker Representatives, Union Members, Shop Stewards and their Colleagues in 2009 by Establishment Bargaining over Union Rights

\begin{tabular}{lcccc}
\hline & \multicolumn{4}{c}{ Effect for establishments with shop stewards } \\
\hline & No bargaining over union rights & Bargaining over union rights \\
\cline { 2 - 5 } & $\mathbf{( 1 )}$ & $\mathbf{( 2 )}$ & $\mathbf{( 3 )}$ & $\mathbf{4})$ \\
\cline { 2 - 5 } Unionised, not representatives & $-0.074^{* * *}$ & $-0.094^{* * *}$ & -0.010 & 0.016 \\
Unionised representatives & $(0.018)$ & $(0.021)$ & $(0.023)$ & $(0.027)$ \\
& $-0.065^{* * *}$ & $-0.052^{* *}$ & -0.027 & -0.002 \\
Non-unionised representatives & $(0.022)$ & $(0.024)$ & $(0.028)$ & $(0.031)$ \\
& -0.010 & -0.005 & -0.000 & 0.015 \\
Observations & $(0.040)$ & $(0.041)$ & $(0.056)$ & $(0.062)$ \\
$R^{2}$ & 2,650 & 2,661 & 1,824 & 1,825 \\
Worker controls & 0,499 & 0,767 & 0,539 & 0,769 \\
Establishment controls & Mincer & Mincer & Mincer & Mincer \\
Weighted & Oui & Effets fixes & Oui & Effets fixes \\
Establishments with a shop steward & Oui & Oui & Oui & Oui \\
Bargaining over union rights & Oui & Oui & Oui & Oui \\
\hline
\end{tabular}

Effect for shop stewards (all establishments)

Method 1 :

Shop Steward

$\begin{array}{cccc}-0.106^{* * *} & -0.148^{* * * *} & 0.016 & -0.031 \\ (0.050) & (0.054) & (0.058) & (0.069)\end{array}$

Non-unionised representatives

$-0.002$

0.021

$-0.047$

0.010

(0.021)

(0.023)

(0.030)

(0.035)

Method 2 :

Shop Steward

$\begin{array}{cccc}-0.095^{*} & -0.049 & -0.016 & -0.075 \\ (0.052) & (0.057) & (0.070) & (0.085)\end{array}$

Non-unionised representatives

$$
\begin{gathered}
-0.059 * * * \\
(0.019)
\end{gathered}
$$$$
-0.066^{* * * *}
$$

(0.022)

(0.024)

Method 3 :

Shop Steward

$\begin{array}{cc}-0.210^{* * *} & -0.239 * * * \\ (0.078) & (0.086)\end{array}$

$-0.034$

$-0.079$

$(0.078)$

0.062

(0.081)

(0.094)

Non-unionised representatives

$$
\begin{gathered}
0.023 \\
(0.059)
\end{gathered}
$$

(0.065)

0.009

0.082

(0.070)

Note: See the notes to Table 1, Box 2 and Bourdieu, BrEDA (2015) for details regarding methods 1, 2 and 3 leading to "probabilistic" estimations for shop stewards only.

The table shows estimates on two different samples according to the existence of negotiations concerning union rights between 2008 and 2010. Columns 1 and 2 focus on establishments that did not have such negotiations while columns 3 and 4 focus on establishments that did have them.

Interpretation: In establishments that did not have negotiations concerning union organisation rights between 2008 and 2010 , union members who are not worker representatives are paid in 2009 on average $7.4 \%$ less than workers who are neither unionised nor representatives (the omitted category), controlling for education, sex, age and establishment characteristics (column 1).

Field: Full-time permanent workers, excluding apprentices, interns and second jobs, with annual declared hours between 900 and 2,200, working in establishments with 10 employees or more in the non-farm business sector.

Source: The employer and employee parts of the 2010 REPONSE survey, matched to DADS data. 
at the establishment and/or firm level, with around half of these negotiations leading to an agreement (Table 5). Considering establishments belonging to firms with over 300 employees, which are required to negotiate over union organisation by the Law of the 20th of August 2008 (Table 5), the negotiation rates are even higher (they almost double) but remain well below $100 \%$, so that the legal requirements are not always respected. ${ }^{6}$ The comparison of 2004 and 2010 does suggest that the Law was applied in a certain number of firms: negotiations and agreements regarding union organisation and employee expression rights rose over the period, and notably in firms with over 300 employees.

Table 6 shows that when specific negotiations concerning union organisation and employee expression rights take place, wage penalties for worker representatives disappear. Direct estimation shows that in 2009 union members and unionised worker representatives suffered a wage penalty only in establishments where there were no negotiations concerning union organisation and employee expression rights between 2008 and 2010 (non-unionised worker representatives do not receive lower wages in any of the specifications). Union-representative wage gaps are therefore not systematic, and bargaining specifically targeted at unions' rights within the workplace seems to be able to reduce or eliminate them. It is however difficult to be sure that the relationship between this type of bargaining and the wage gap is causal. It might rather be the case that establishments with better-paid worker representatives are more likely to engage in bargaining, so that the estimation results in Table 6 reflect selection. However, it remains likely that the threat of litigation for union discrimination (Chappe, 2015; Semaine Sociale Lamy, 2004) has, at least in a number of cases, led to successful negotiations of remedial wage rises for unionised worker representatives. This shows that those negotiations do not always reflect legal compliance on the part of firms that already pay their worker representatives the same as their other employees.

\section{Why are Shop Stewards Paid Less?}

A common interpretation of differences in wages for given levels of experience and education is discrimination. However, in the absence of compelling evidence of discrimination, economists also consider that wage gaps may reflect unobserved differences in ability or productivity. Along the same lines, in legal terms, wage discrimination would be dismissed for the benefit of the doubt except in the exceptional

\footnotetext{
6. It is possible that the Law be respected at the firm level, but that the management representative at the establishment level is not aware of this. Union agreements at the firm level may not then be applied in all of the firm's establishments. It is however hard to believe that this applies to all of the $40 \%$ of establishments with shop stewards belonging to a firm with over 300 employees in which the management representative declared no negotiation over union organisation. There are thus certainly a considerable percentage of establishments that do not apply (all of) the provisions of the Law of the 20th of August 2008.
} 
cases where the employee, on whom the burden of proof falls, can show that he is not less productive. However, there have been considerable legal changes in the burden of proof, with a movement towards the employer having to justify wage differences based on productivity (CHAPPE, 2013).

Wage discrimination is defined both in Law and Economics as the violation of a principle: the equity principle in Economics -wages reflect productivity- and the principle of equality in Law - "equal pay for equal work". As the work of two employees is in reality always different, and as the (marginal) individual productivity is almost never perfectly observed (notably in the case of joint production processes), these principles cannot usually be checked, rendering formal proof of wage discrimination almost impossible, either by economists, by employees who demand compensation, or by the employer who is accused of discrimination.

While these considerations complicate the establishment of definitive statistical proof, they do not exclude the discussion of the different mechanisms that lie behind wage gaps, whether these effectively be types of discrimination or the selection of employees according to their ability. We below distinguish five different complementary mechanisms that can produce differences in wages and promotion rates. The first three are taste-based discrimination (BECKER, 1971), adverse selection (so that worker representatives are less productive) and statistical discrimination (ARROw, 1973; PHELPS, 1972). These three are part of the standard set of economic explanations of differences in labour-market outcomes between social groups. We propose to add to this set a more atypical type of discrimination, which is both strategic and particular to the representation of workers' collective interests. It is this explanation that we find the most persuasive, although we cannot definitively reject the others, and in any case the sources of wage gaps may in some cases be complementary. Last, we discuss the possibility of self-censorship behaviour by worker representatives, who may renounce personal gain in order to defend the interests of other workers.

\section{Taste-Based Discrimination}

Under taste-based discrimination against a social group the employer has a preference for individuals who do not belong to this group. Hostility towards unions and their members may then be reflected in lower wages for the latter. This taste cannot, at least legally, justify the employer's choices regarding hiring, pay or firing, but there are nonetheless many testimonies as to its existence.

The principle of taste-based discrimination against union members is nonetheless difficult to dissociate from the economic and social role that these individuals play in the firm, unless we can say that union members have specific characteristics that are independent of this role and which render the firm hostile towards them. Any

7. Michelin is a good example here: see Mousli M. (2011), «Un patron paternaliste et antisyndical », Alternatives économiques, no 305, September, p. 78. 
aversion felt by the employer with respect to unions is likely not totally independent of the fact that unions, as incarnated by unionised worker representatives, defend interests that are opposed to their own. In this sense, taste-based discrimination overlaps with the strategic discrimination that we will discuss below, even though the first reflects a global antipathy between unions and firms, while the second refers to a local discrimination at the level of the establishment, against certain worker representatives linked to their particular role during bargaining.

\section{Adverse Selection}

Rather than reflecting employer aversion, the wage gap for union members could rather reveal their lower productivity. This may be the point of view of some employers, for whom union membership and engagement are a way of avoiding productive work and shirking. Union members will then be less productive, as only those who are less committed to their work become unionised and become representatives, or because union membership diverts individuals from their directly productive work over and above their statutory time devoted to union activities. Lower union promotion rates can then be explained by the lower productivity of union workers.

These hypotheses are almost impossible to evaluate empirically: there are no datasets rich enough to produce an exact measure of worker productivity, to the extent that the latter can even be measured. We can however make a number of remarks about this interpretation, which is also sometimes put forward by employers as a justification. First, union wage gaps rise with employee tenure in the establishment: they are practically zero for workers with low tenure in both the 2004 and 2010 data. ${ }^{8}$ Workers who become unionised or worker representatives at the beginning of their establishment career are therefore not penalised, which suggests (without representing a formal proof) that they were not already less productive when they became unionised. In other words, union members and worker representatives do not seem to be systematically selected from lower-wage and lower-productivity workers before their unionisation.

If it is lower productivity that explains the wage penalty suffered by union members and worker representatives, we would expect this to become more apparent after joining or taking up office, as it is at this moment of engagement that workers would start to invest less in their work. This possibility requires a comment, which applies specifically to worker representatives.

These latter, given the time devoted to employee delegation, have statutory activities that are not exactly comparable to those of their colleagues over the working week. The particular legal provisions that apply to representatives prohibit any wage

8. See BREDA (2014) and BouRdiEu, BREDA (2015). One difficulty here is that only worker tenure in the establishment is measured. However, complementary analyses using the "worker representative" part of the survey reveal that it is rather tenure as a representative in the establishment that explains the sentiment of discrimination felt by representatives, and not their tenure in the establishment (BREDA, 2014; BouRdiEU, BREDA, 2015). 
penalty related to these activities, the cost of which is to be borne by the employer. The time off for these activities does however affect the organisation of work at the establishment, and could potentially be behind the difference in promotion rates: a firm wishing to promote a worker to a position involving a heavy workload may choose a worker without time devoted to employee delegation activities who can thus invest themselves fully in the new job (see CHAPPE et al., 2016, on this point). If we have to file this situation into one of the categories above, should it be classified as discrimination or selection?

From the economic point of view, the difference in effective work-related activity formally suffices to void the possibility of discrimination in this case. The adoption of this stance does however systematically legitimise the wage penalties suffered by unionised worker representatives without any discussion of the real motives that may lie behind these penalties. The current legal position departs from this position and, on the contrary, opts for an interpretation that is more favourable to employees, in that discrimination is possible even though it is impossible to establish exactly the condition of "equal pay for equal work". The numerous union discrimination lawsuits that have been won bear witness to this position.

An alternative approach, that is perhaps more apt if we take the strict economic point of view, is to value the time devoted to employee representation by recognising the skills acquired by worker representatives. Along these lines, the Law of the 17th of August 2015 renders obligatory the evaluation of the skills acquired during the term of representation by external certification bodies or the management of the firm's own Human Resources Department. External certification, which already existed in 2015, does not necessarily guarantee adequate career advancement. In addition, this mostly applies to permanent union officers or those elected for terms in senior union positions, leaving to one side the majority of representatives who have only little statutory time off for delegation activities (CHAPPE et al., 2015). The direct evaluation of skills acquired by union representatives by the firm runs into a fundamental problem: when there is a conflict between the interests of the workers and the firm (which is generally the case when there is bargaining over the sharing of profits), then worker representatives run the risk of "displeasing" the firm. We can then legitimately ask how the evaluation of worker skill acquisition by firms can work in practice: does this not rather institutionalise a type of labour relations which favours the firm over the workers?

\section{Statistical Discrimination}

A type of discrimination directly related to selection explains the worse careers of union members by the belief, legitimate or otherwise, that they are less productive. This argument only holds in environments where either productivity or the work carried out are only imperfectly measured. In this case, the employer may appeal to indirect information on productivity or ability. Here lower union wages are not nec- 
essarily explained by lower union productivity, but rather by the employer's belief that this is the case. This kind of argument is in general evoked for hiring discrimination rather than discrimination at work in general, which in principle is based on long-term interactions between the firm and the worker, where the work carried out by the latter becomes increasingly observable.

A similar phenomenon to the dynamic selection described above could however be at work: the employer may think that union membership or worker representation do not indicate lower initial ability, but rather a lack of investment in the job. Considering, rightly or wrongly, that union members furnish less effort, employers are less likely to promote and reward them. As work on statistical discrimination has shown (for example, LundBERG, STARTZ, 1983; COATE, Loury, 1993; Loury, 2002), beliefs can be self-fulfilling: knowing in advance that employers will consider their union engagement to reflect a lack of investment in the job, union members have less incentive to make investments in their job that will likely not be rewarded at their fair value. This rational lower effort by union workers should then be combined with another, equally rational, phenomenon of the selection at entry of those workers who are prepared to renounce their professional career. While we here present these situations in a rather caricatural style, these vicious circles should not be dismissed. The negative view of labour relations and its actors on the part of employers produces conflictual labour relations with a particular type of worker representatives: those who are ready to give up their careers.

The evidence from field surveys on these phenomena is however more nuanced: certain union members, and notably those in elected office in the firm, are sometimes scorned, including by other employees, and accused of taking it easy and taking advantage of their time off for statutory activities and their privileged position; however they are also often considered as particularly active and enterprising, sometimes over-invested in the firm, their worker representation activity and their job, if only not to be considered at fault by the employer, who is ready to dismiss them for the slightest digression. This is reflected in the statistics on delegation hours: unionised worker representatives, and especially shop stewards, are more likely than nonunionised worker representatives to have time off for representation activity, and of longer duration. Even so, they often declare that they go over this official figure, and spend extra time on representation activity (PAK, PIGNONI, 2014). This is all the more true when they belong to the CGT union (eight times more likely to go over the official time-off figure than non-unionised worker representatives, holding constant the characteristics of the establishment and the firm), Unsa (the Union nationale des syndicats autonomes - National Union of Autonomous Trade Unions), Solidaires, or independent unions (six times more likely). The example of the dismissal of Nordine, a member of the Sud union at GRDF (the gas distribution subsidiary in France), and the long fight led by his union and its members to establish the legal recognition of the discriminatory nature of this decision and his reinstatement is one of many documented examples showing that shop stewards produce work of quality, 
even though, obviously, the employer may not acknowledge this in times of conflict (BARNIER et al., 2011).

\section{Strategic Discrimination}

Hostility towards union members could in particular be the result of the advocacy position that union membership represents. From a theoretical point of view, over and above any taste-based discrimination against unions, or lower pay reflecting lower (supposed or actual) productivity, the lower pay of union representatives could reflect that they express opposing interests, coming in part from union organisations that are external to the firm. In this case, the employer may be tempted to penalise union members independently of the quality of their work, and all the more so that their union activity represents a threat to the interests of the business during bargaining. ${ }^{9}$ The lower wages of union workers here, as they are independent of the work carried out as an employee, are discriminatory in the legal sense.

The discrimination exerted by the firm is then strategic, and does not refer to the worker himself or herself, but rather the potentially successful demands that they will make during bargaining. The goal is to dissuade workers from becoming shop stewards, and discourage participation in bargaining with the firm and union movements for higher wages.

The effectiveness of this practice depends not only on the effect that it has on shop stewards themselves, but also on the signal that it sends to all workers to dissuade support for union activity. These indirect dissuasive effects can be considerable. A survey by TNS-SOFRES revealed, for example, that over one-third of workers mention the fear of reprisals as one of the reasons for the low rate of union density in France. The absence of shop stewards in around two-thirds of establishments with over 10 workers (our own calculations), in which their presence is required by Law, is another indication of the hesitation of workers to engage in union activity. While the strategy of discriminating against the most active shop stewards does not necessarily weaken them immediately, it stands a good chance of undermining the extent of collective action in the medium term: firstly because workers will be hesitant to directly support union action, and second because some workers will even break ranks with the union as a result of the negative signal emitted by the firm against them. ${ }^{10}$

The strategic discrimination wage penalty, which is likely only part of overall wage discrimination, does not prevent certain workers from becoming shop stewards. This does not however mean that the strategy has failed. These workers may

\footnotetext{
9. As shown strikingly and systematically in the special issue of Agone on this subject, union discrimination does not (only) lead to an average statistical wage effect but on the contrary consists of policies that are targeted against certain individuals that can cover non-wage domains. There are a number of different ways of taming industrial conflict, as set out in GiRAUD (2013).

10. See BREDA (2011) for the full analysis of strategic discrimination in a dynamic bargaining model.
} 
well have other motivations than their career in choosing to be the mouthpiece of the union, although this does not mean that workers will not be affected or weakened, at least in the longer run, by this discrimination. The depictions of workers who are only interested in their salary or, on the other hand, the heroic union worker who sacrifices his career for the union cause and who is only strengthened by employer harassment are extreme cases that have to be qualified. Many testimonies reveal, for example, that the sacrifices initially accepted by some union members finally lead to discouragement and even withdrawal (see the experience related by Christian Corouge in his interview with Michel Pialoux in Résister à la chaîne, 2011). The intense use of contractual termination by worker representatives when this scheme was introduced (BOURDIEU, BREDA, 2015) suggests that many representatives were ready to quit their firm in exchange for severance pay, which they were not able to do beforehand due to the control that the labour inspectorate (the inspection du travail in France, which ensures the respect of labour Law) had over the conditions of their dismissal.

It is difficult to know if the demands made by unions would have been less strong had shop stewards been better treated. But the reverse assertion, that discrimination against shop stewards led to greater union demands, seems unlikely as a general rule. There have of course been specific cases where particularly visible discrimination has led to substantial and costly strife, or criminal convictions as has been frequently been observed over the past 15 years. Overall, it nonetheless seems that in most cases the strategy of discouraging union activity by punishing its leaders is effective for firms.

The question then arises of whether it would not have been simpler and more efficient for firms to buy off shop stewards so that they moderate their demands. The cost of better treatment, via pay or otherwise, for a small number of worker representatives counts for little compared to the benefits that firms can reap by defusing some of the union's demands concerning all of the firm's workers.

There are a number of real-world examples of this kind of strategy. Notable cases of large-scale corruption (the slush funds of the Union des industries et des métiers de la métallurgie [Union of Metal-Working Trades and Industries - UIMM] to facilitate labour relations, notorious cases of abuse of some works councils, etc.) or the existence of company unions in certain firms are examples of collusion between firms and worker representatives, to the detriment of workers' interests. However, these strategies of collusion are most often not articulated as such by those who implement them, but rather evolve as a kind of tacit agreement between representatives and firms who share common individual interests.

This strategy does have its limits. The first is that outright collusion becomes visible and leads to worker representatives losing the confidence of workers. Anything that looks like favouritism is looked upon badly by workers, even if it seems justified. The example of standby pay, sometimes negotiated in large firms by some representatives due to the frequent requests that they receive from management is 
an apt one here: some see this as a fair reward for the delegates' implication in their work, while others consider it as a way for the employer to buy good labour relations (see the case of GRDF described by CHAPPE et al., 2016). A second limit comes from the multiplicity of unions present in each firm: as these are in competition with each other, they are often quick to denounce any collusion between a union and the employer. It is then difficult for the latter to engender a policy of collusion with the whole group of union representatives.

We should add here that the cases of collusion (where the representative is bought off) and, on the contrary, conflict (where the representative is discriminated against) may in practice be complementary and co-exist. The dissuasion via discrimination when union demands are too strong is all the more credible if it is sometimes implemented by the firm. This can help to set up an understanding with union representatives who fear being penalised. The denunciation of corruption might not suffice to prevent it, but may only serve to increase division between unions and, finally, weaken workers' demands.

In the end, we are not able to conclude here as to the motives that drive firms to penalise shop stewards rather than buying them off. We might hypothesise that the firm will start by trying to ensure the acquiescence of worker representatives via more or less open preferential treatment but, if this does not work or faced with union members who are particularly active and little inclined to compromise, may well turn to discrimination instead. From an empirical point of view, if the observed wage penalties do effectively reflect strategic behaviour, we can conclude that on average discrimination outweighs any preferential treatment in wages. The existence of strategies with opposing wage effects does mean that when we measure discrimination by the average wage penalty, we may miss out, within the same firm, cases of bonuses paid to compliant representatives and greater wage penalties for those who are not. The distinction between unionised and non-unionised worker representatives is a good illustration of this potential diversity. And even within the group of unionised worker representatives, the average wage penalty of $4 \%$ likely encompasses a wide variety of situations. This heterogeneity is likely greater than amongst union members who are not representatives, who are less likely to be bought off as they have no official role affecting the functioning of the firm. As a result, the wage penalties faced by unionised representatives and unionised non-representatives, that are on average the same, do not necessarily reflect the same level of discrimination: as they have more strategic interactions with the firm, unionised representatives may be at the same time both more discriminated against and receive more preferential treatment than unionised non-representatives.

Empirically, it is mainly the comparison of the situations of different types of worker representatives, according to their official duties, the union to which they belong, and the existence of bargaining or conflict at the firm which leads us to conclude in favour of the hypothesis of strategic discrimination. The wage penalties incurred by worker representatives are in fact systematically aligned with the poten- 
tial cost that they could impose on the firm: the more likely it is that the actions of representatives will be effective and lead to wage gains at the firm's expense, the less the representatives are paid.

The first comparison is between unionised and non-unionised worker representatives. The statistics on representative activity (PAK, PIGNONI, 2014) show that unionised worker representatives are more active: they devote more time to their responsibilities and spend more time with workers and representing workers with the firm. They also make more propositions regarding the functioning of the firm and are more likely to call on outside experts or legal structures; they also draw more often on union structures that are external to the firm. As they are more visible, they interact more with the employer. It should be added that, due to the support of the union structure, they are also better trained and better prepared during the formal phase of bargaining with the firm. This is confirmed by the external parties that intervene in the case of conflict or where psycho-social risks have been identified: union representatives know the case better and are less likely to be manipulated than their non-union colleagues.

The most important distinction, however, is that regarding the function that is in principle transferred to shop stewards: the bargaining over wages, employment and work conditions that usually takes place every year with the employer. Contrary to other representatives whose actions may, at least on paper, rather enhance firm performance, shop stewards are restricted to participation in a zero-sum game: the gains that they obtain are principally at the employer's expense. In other words, it is shop stewards who determine the outcome of the fundamental conflict of interest between workers and shareholders: how to share the benefits of production. Employers have an incentive to limit the influence of shop stewards via discrimination as it is these latter who, notably through wage bargaining, lead to lower profits. The analysis of shop stewards' outcomes depending on whether they negotiated wages with the firm provides evidence in favour of this interpretation: the 30\% of shop stewards who do not negotiate with the firm, even though they are mandated to do so, do not suffer from lower wages, while those that do are significantly penalised (with wages that are between 10 and 20\% lower), and even more so when the negotiation did not lead to complete agreement with the firm. The estimated wage penalties are also higher when there are strikes or other types of conflict with the employer, and especially when this conflict was lost by the employees and covered a significant percentage of workers in the establishment. ${ }^{11}$

All of these results suggest greater union wage penalties when they are not in a position with greater power (having lost a conflict) and when the costs they can impose on the firm are more significant. This diversity of wage effects is all the more remarkable that it was not possible to match the wage penalties of shop stewards to

11. All of these results appear in BourdieU, BREDA (2014). 
more direct measures of their activity, such as hours spent on union work or protection against firing (BREDA, 2014).

Our theory of strategic discrimination does however include a grey area: we cannot determine if this represents discrimination linked to the local representation of the workers in the firm, or rather discrimination linked to the broader representation of the union's interests. While the duties of shop stewards are to negotiate and make claims in the interests of the firm's employees, they also take into account the wider interests and demands of the union to which they belong. What we have shown is that the wage penalties suffered by worker representatives rise with their bargaining power. However, we cannot determine whether the interests for which they bargain are those of the firm's workers or rather of the union that they represent.

\section{Self-Censorship of Worker Representatives}

One last explanation can be put forward: the lower wages of certain worker representatives may be explained by self-censorship, where they refuse their own personal interest in order to devote themselves to defending other workers. A number of testimonies reveal that worker representatives consider lower salaries as normal: firstly because they are used to them and have never considered the alternative, and secondly (and perhaps more importantly), because they are very committed to the recognition that goes with their work, which they consider to be incompatible with high earnings (Beaux, Pialoux, 1999; Corouge, Pialoux, 2011). The most committed shop stewards are also suspicious of promotions and pay rises. Their wage sacrifice for their colleagues is the ultimate proof of their incorruptibility. Regarding a compensation agreement, Fred Dijoud, a representative of the CFDT (Confédération française démocratique du travail - French Democratic Confederation of Labour) union, quoted by Libération explained that "Some of my colleagues refused to sign the agreement [of a remedial wage rise for union members]. They say that they knew the risks of their union activity". A member of the CGT union also claimed that "to be discriminated against is proof that we have not been bought off by the bosses!" 12

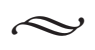

We find average wage gaps of around 3 to $4 \%$ against union workers as compared to non-union workers of the same age, sex and education. These penalties are larger and can exceed $10 \%$ for those, among union members, who are shop stewards and therefore participate in obligatory bargaining with the firm. Union members who are worker representatives but not shop stewards have the same wage gap as union members who are not representatives.

12. See Hervé Nathan, «Discrimination syndicale : les entreprises se rachètent une conduite », Libération, April 2nd 2002. 
While we cannot prove beyond doubt that these wage gaps reflect discrimination, in the legal sense of the term, there are a number of suggestive pieces of evidence. Wage discrimination is in addition the most objective part (legally and statistically measurable) of a whole set of different types of union discrimination that are well-documented in different contributions. Union discrimination is different from most other types of discrimination in the sense that it is the consequence of an individual choice (taking a union mandate). As such, it may well reflect the conflict of interest and the balance of power between workers and the firm more than any belief on the part of the firm as to the lower ability of union members, or taste-based discrimination against them by the firm.

To render the balance of power between workers and firms more favourable for the former in the context of rising inequality and worsening work conditions we need to improve the capacity of worker representatives to express themselves and defend the interests of the workers that they represent. To do so, we could encourage workers to take a greater interest in the actions of their representatives, so that they can support and defend them in obvious cases of harsh treatment or malfunctioning. In this perspective, this article suggests that we could start by watering down the subordinate relationship between the firm and the worker representative in order to limit the possibility of discrimination or collusion, and on the contrary increase the degree of dependency of representatives on the workers that they represent.

\section{REFERENCES:}

Arrow, K. J. (1973). "The Theory of Discrimination." In O. Ashenfelter, A. Rees (Eds.), Discrimination in Labor Markets (pp. 3-33). Princeton (N. J.): Princeton University Press.

Barnier, L.-M., Cochin, Y., Debrégeas, A., Gélot, D., Menghini, L., Pignoni, M.-T. \& ReYnosa, S. (2011). Répression et discrimination syndicales. Paris: Fondation Copernic, Syllepse.

Beaud, S., Pialoux, M. (1999). Retour sur la condition ouvrière. Enquête aux usines Peugeot de Sochaux-Montbéliard. Paris: Fayard.

BeCKeR, G. S. (1971). The Economics of Discrimination. Chicago: London, University of Chicago Press.

BOURDIEU, J., BREDA, T. (2015). Les Employeurs face aux représentants du personnel : une situation de discrimination stratégique ? Unpublished Report (written for a project on worker representatives financed by the DARES). Online http://www.parisschoolofeconomics.com/ breda-thomas/working_papers/Bourdieu_Breda.pdf (accessed 23 October 2017).

BREDA, T. (2011). Syndicats, négociations, ou capitalisme familial : effets sur les salaires et la protection de l'emploi. ( $\mathrm{PhD}$ Thesis, École des hautes études en sciences sociales).

BREDA, T. (2014). «Les délégués syndicaux sont-ils discriminés ?» Revue économique, 65(6), 841-880. 
ChAPPE, V.-A. (2013). «Dénoncer en justice les discriminations syndicales : contribution à une sociologie des appuis conventionnels de l'action judiciaire. »Sociologie du travail, 55(3), 302-321.

ChAPPE, V.-A. (2015). « Les discriminations syndicales saisies par le droit à PSA. » La Nouvelle Revue du travail, 7. Online https://nrt.revues.org/2324 (accessed 23 October 2017).

Chappe, V.-A., Denis, J.-M., Guillaume, C. \& Pochic, S. (2015). Discrimination syndicale et reconnaissance des parcours syndicaux : les deux faces du dialogue social à la française? Report for the CFDT, Agence d'objectifs de l'Ires.

Chappe, V.-A., Guillaume, C. \& Pochic, S. (2016). « Négocier sur les carrières syndicales pour lutter contre la discrimination. Une appropriation sélective et minimaliste du droit. » Travail et Emploi, 145, 121-146.

CoAte, S., Loury, G. C. (1993). "Will Affirmative-Action Policies Eliminate Negative Stereotypes?” American Economic Review, 83(5), 1220-1240.

Corouge, C., Pialoux, M. (2011). Résister à la chaîne. Dialogue entre un ouvrier de Peugeot et un sociologue. Marseille: Agone.

GIRAUD, B. (2013). « Derrière la vitrine du "dialogue social” : les techniques managériales de domestication des conflits du travail. » Agone, 50, 33-63.

LOuRy, G. C. (2002). The Anatomy of Racial Inequality. Cambridge (Mass.): Harvard University Press.

Lundberg, S. J., Startz, R. (1983). "Private Discrimination and Social Intervention in Competitive Labor Market.” American Economic Review, 73(3), 340-347.

PAK, M., PignONI, M.-T. (2014). «Les représentants du personnel : quelles ressources pour quelles actions ?» Dares Analyses, 84.

Phelps, E. S. (1972). "The Statistical Theory of Racism and Sexism”, American Economic Review, 62(4), 659-661.

Semaine sociale Lamy (2004). « Discrimination syndicale : la stratégie de la CGT. Entretien avec François Clerc, chargé des dossiers en discrimination à la CGT. » Semaine sociale Lamy, 1190, 3-10. 


\begin{abstract}
APPENDIX
Two methodological choices have been made in Table 1. First, we consider only employees with a full-time permanent contract, excluding apprentices, interns and those in second jobs, with between 900 and 2,200 declared annual hours. The aim of these restrictions is to exclude workers in insecure jobs, who are for this reason less well-paid than worker representatives and their colleagues. As a result of the job that they carry out, worker representatives are less likely to be on temporary contracts or to work part-time. We thus consider the wage gap between worker representatives and their colleagues among those with the stable jobs (the "insiders"). On the contrary, if we retain all workers in the analysis, including those with more insecure jobs, we predictably obtain somewhat smaller wage gaps (BOURDIEU, BREDA, 2015, Table A1). ${ }^{13}$

Our second choice consists in the use of the weights supplied by the DARES in the estimated wage equations. There is no consensus as to the use of weights in econometric analysis. Some believe that the causal impact of one variable on another should not be established by weighting the observations. But our goal here is not to measure the causal impact of being a worker representative on wages, but rather to establish the size of these wage gaps in the first place. With this descriptive goal, we believe that the use of weights in the estimations is justified in order to produce estimations that are the most representative of the whole of the labour market. If we do not use weights we obtain wage gaps that are smaller in size (BOURDIEU, BREDA, 2015, Table A2).
\end{abstract}

\footnotetext{
13. Even though we believe it to be justified in the current analysis, our methodological choice of concentrating on "insider" employees can be criticised for the potential selection bias that it creates. We therefore checked whether the main results presented here continued to hold when we keep part-time and fixed-term contract workers in the sample, adding additional control variables for these statuses in the empirical analysis. In general, the wage penalties found in this expanded sample are:

- slightly lower for unionised non-representative workers;

- somewhat larger for unionised representatives (and shop stewards) in the specifications without establishment fixed effects;

- a little lower for unionised representatives (and shop stewards) in the specifications including establishment fixed effects. With these limited exceptions, the results were very similar.
} 